\title{
Extraction of Aluminium from Kaolin: a Comparative Study of Hydrometallurgical Processes
}

\author{
Konstantina Kyriakogona, Ioanna Giannopoulou, Dimitrios Panias \\ National Technical University of Athens, School of Mining and Metallurgical Eng. \\ Iroon Polytechniou 9 - Zografos, Athens, Greece \\ k.kiriakogona@outlook.com; ioangian@metal.ntua.gr; panias@metal.ntua.gr
}

\begin{abstract}
The increase of aluminium demand globally, raises the interest of developing alternative technologies to produce alumina from non-bauxitic sources, especially clays. This paper studies the extraction of aluminium from kaolin through leaching process, using aqueous solutions of acids and bases, as leaching agents. For this study, crude kaolin excavated in Milos Island, Greece, was used. Before leaching, crude kaolin was calcined; calcination achieves the dehydroxylation of kaolinite, which is the main mineralogical phase of kaolin and its transformation to metakaolin, an amorphous Al-Si phase from which aluminium is easily leached. Calcination of the crude kaolin used in this work was taken place at $850^{\circ} \mathrm{C}$ for $2 \mathrm{~h}$, given that these conditions revealed as optimum in the relevant experimental investigation. Leaching of aluminium from the calcined kaolin was performed with aqueous solutions of mineral acids ( $\mathrm{HCl}, \mathrm{HNO}_{3}$ and $\left.\mathrm{H}_{2} \mathrm{SO}_{4}\right)$, organic acids $\left(\mathrm{C}_{2} \mathrm{H}_{2} \mathrm{O}_{4}, \mathrm{C}_{2} \mathrm{H}_{4} \mathrm{O}_{2}\right.$ and $\left.\mathrm{C}_{6} \mathrm{H}_{8} \mathrm{O}_{7}\right)$ and bases $\left(\mathrm{NaOH}, \mathrm{KOH}\right.$ and $\left.\mathrm{NH}_{4} \mathrm{OH}\right)$. All leaching experiments were performed under constant conditions, regardless the leaching agent used. According to the experimental results, acids were proved more effective in aluminium extraction, than bases. However, aluminum extraction was accompanied by simultaneous extraction of $\mathrm{Si}$ which comprises an important impurity for the production of alumina from the pregnant liquor. Based on this consideration, oxalic acid was revealed as the most effective leaching agent, yielding more than 75\% extraction of $\mathrm{Al}$ and less than 5\% Si extraction.
\end{abstract}

Keywords: kaolin, aluminium, extraction, leaching

\section{Introduction}

The global increase of aluminium demand raises the interest of developing alternative technologies to produce aluminium from low-grade ores. To this direction, intensive research and engineering efforts have been carried out in many countries on the extraction of alumina from various naturally occurring non-bauxitic sources, especially clays [1-3]. Clays are abundant minerals, consisting mainly of aluminosilicate minerals with traces of iron oxide and alkali-metals oxides [4]. Among the different clays, kaolin seems to be a more attractive candidate for alumina production, due to its high aluminium content. Kaolin consists mainly from kaolinite with the representative chemical formula $\mathrm{Al}_{2} \mathrm{O}_{3} \cdot 2 \mathrm{SiO}_{2} \cdot 2 \mathrm{H}_{2} \mathrm{O}$, which is a two layer silicate mineral that typifies the kaolin group. The main contaminants of kaolin are quartz and mica $(10-45 \%)$, as well as iron oxide (1-10\%) [4].

The extraction of alumina from kaolin has been widely investigated with a range of acid and alkali hydrometallurgical processes. Leaching of aluminium from calcined kaolinitic clays with $\mathrm{HCl}$ or $\mathrm{H}_{2} \mathrm{SO}_{4}$ solutions is proposed with the sequent precipitation / crystallization of aluminium salts and their thermal decomposition to produce alumina [2]. In addition, the ammonium sulphate sintering process is investigated for the extraction of aluminium, as well as the leaching with sulphuric acid and ammonium sulphate solutions [5]. However, little information exists, concerning the comparison of the different processes used for the extraction of aluminium from clays.

The purpose of this study is to compare the efficiency of a range of leaching agents on aluminium extraction from calcined kaolin and to gain a preliminary understanding of interactions between the different leaching agents and the calcined kaolin that affect the process efficiency.

\section{Materials and Methods}

In this study, a sample of crude kaolin clay originated from Milos Island, Greece, was used as raw material. The kaolin sample was ground to a particle size less than $250 \mu \mathrm{m}$, before calcination. Chemical analysis of kaolin (Table 1) was 
performed by X-Ray Fluorescence (XRF) Spectroscopy and 4-Acids dissolution method (HCl, HNO3, HF and HClO4) followed by determination of the different elements with Atomic Absorption Spectroscopy (AAS) technique. L.O.I. was determined after heating at $1000 \mathrm{oC}$ for $30 \mathrm{~min}$. The X-Ray diffraction (XRD) analysis of kaolin indicated that it is mainly composed from kaolinite and christobalite, while quartz is also present as a secondary phase. The XRD analysis of kaolin, as well as of the kaolin samples after calcination and of the solids taken after leaching experiments, was performed with a Bruker D8 Focus X-Ray Diffractometer with $\mathrm{Cu}$ Ka radiation and $\lambda=1.5418 \AA$ ( $40 \mathrm{kV}$ and $30 \mathrm{~mA}$ ); specimens were stepscanned at the range of 20 per min with 2 theta ranged from 20 to $70 \mathrm{o}$. The same solid samples were also analysed by FTIR technique. The infrared spectra were recorded in the region of $4000-650 \mathrm{~cm}-1$ and collected using the Attenuated Total Reflection (ATR) technique (Perkin Elmer 2000 analyser).

Table 1: Chemical analysis of kaolin samples, crude (KAO) and calcined $(\mathrm{KC})$. Calcination conditions are given in parenthesis (temperature; time).

\begin{tabular}{|l|r|r|r|r|r|r|r|r|r|}
\hline $\begin{array}{l}\text { Sample } \\
\text { code }\end{array}$ & KAO & \multicolumn{1}{|c|}{$\begin{array}{c}\mathrm{KC} \\
(650 ; 60)\end{array}$} & $\begin{array}{c}\mathrm{KC} \\
(650 ; 90)\end{array}$ & $\begin{array}{c}\mathrm{KC} \\
(650 ; 180)\end{array}$ & $\begin{array}{c}\mathrm{KC} \\
(750 ; 90)\end{array}$ & $\begin{array}{c}\mathrm{KC} \\
(850 ; 60)\end{array}$ & $\begin{array}{c}\mathrm{KC} \\
(850 ; 90)\end{array}$ & $\begin{array}{c}\mathrm{KC} \\
(850 ; 120)\end{array}$ & $\begin{array}{c}\mathrm{KC} \\
(950 ; 90)\end{array}$ \\
\hline Oxides & \multicolumn{7}{|c|}{ mass (wt\%) } \\
\hline $\mathrm{Al}_{2} \mathrm{O}_{3}$ & 20.20 & 21.86 & 21.31 & 21.22 & 22.29 & 22.02 & 20.25 & 21.33 & 21.44 \\
\hline $\mathrm{SiO}_{2}$ & 71.18 & 78.14 & 78.11 & 78.15 & 77.71 & 77.98 & 79.23 & 77.86 & 78.56 \\
\hline $\mathrm{Fe}_{2} \mathrm{O}_{3}$ & 0.09 & 0.00 & 0.10 & 0.09 & 0.00 & 0.00 & 0.12 & 0.09 & 0.00 \\
\hline $\mathrm{TiO}_{2}$ & 0.37 & 0.00 & 0.48 & 0.54 & 0.00 & 0.00 & 0.40 & 0.39 & 0.00 \\
\hline L.o.I. & 8.07 & & & & & & & & \\
\hline TOTAL & 100.00 & 100.00 & 100.00 & 100.00 & 100.00 & 100.00 & 100.00 & 100.00 & 100.00 \\
\hline
\end{tabular}

Calcination of kaolin was performed in a laboratory muffle furnace, under open air conditions and for different temperatures $(650,750,850$ and $950 \mathrm{oC})$ and times $(90,120$ and $180 \mathrm{~min})$. In each calcination test, a $10 \mathrm{~g}$ sample of kaolin was heated at the predefined temperature with a ratio of $3 \mathrm{oC}$ per min; after reaching the desired temperature, the sample was left at this temperature for the predefined time and then, the furnace was cooled down. The weight of samples before and after thermal treatment was measured, in order to determine mass loss during calcination process. Based on these calculations and taking into consideration the L.O.I. measurement of the crude kaolin, the optimum calcination conditions for the crude kaolin were selected. The calcined kaolin samples were analyzed by XRF and 4-Acids dissolution / AAS techniques (Table 1), while their mineralogical phases were identified by XRD method. According to the XRD analysis, kaolinite is absent from the XRD patterns of the calcined kaolin samples, while an amorphous silicate phase seems to be formed.

Leaching experiments were performed with kaolin calcined at $850 \mathrm{oC}$ for $120 \mathrm{~min}$ and aqueous solutions of $1 \mathrm{~N}$ concentration of the mineral acids $\mathrm{HCl}, \mathrm{HNO} 3$ and $\mathrm{H} 2 \mathrm{SO} 4$, the organic acids $\mathrm{C} 2 \mathrm{H} 2 \mathrm{O} 4, \mathrm{C} 6 \mathrm{H} 8 \mathrm{O} 7$ and $\mathrm{C} 2 \mathrm{H} 4 \mathrm{O} 2$ and the bases $\mathrm{NaOH}, \mathrm{KOH}$ and $\mathrm{NH} 4 \mathrm{OH}$. Experiments have been conducted in a $500 \mathrm{~mL}$ glass reaction vessel with a 5-neck lid. Leaching temperature was kept constant at $80 \mathrm{oC}$ in all the experiments, using a laboratory heater equipped with a J-type thermocouple and the appropriate controller. A glass condenser was also adapted to the vessel lid, cooling the produced vapors during the experiments. In each test, $300 \mathrm{~mL}$ of leaching solution was added into the reactor and heated under stirring $(500 \mathrm{rpm})$, until the solution temperature reached $80 \mathrm{oC}$. Then, $3 \mathrm{~g}$ of calcined kaolin was added into the reactor (pulp density equal to $1 \mathrm{~g} / 100 \mathrm{~mL}$ ) and the formed slurry started to be stirred. The experimental time has been counted after the formed slurry reached $80 \mathrm{oC}$. During each experiment, samples of $5 \mathrm{~mL}$ were withdrawn at predefined time intervals $(0.5,1,2,4$ and $6 \mathrm{~h})$ and their concentration in $\mathrm{Al}$ and $\mathrm{Si}$ was determined by AAS. At the end of each experiment $(24 \mathrm{~h})$, the slurry was filtered and the resulted solution was analyzed for $\mathrm{Al}$ and $\mathrm{Si}$ content, while the filtrate was dried and then, analyzed by XRD method. 


\section{Results and Discussions}

\subsection{Calcination of Crude Kaolin}

Calcination of kaolin results in the removal of the hydroxyl ions bound in kaolinite $\left(\mathrm{Al}_{2} \mathrm{O}_{3} \cdot 2 \mathrm{SiO}_{2} \cdot 2 \mathrm{H}_{2} \mathrm{O}\right)$, thus destroying its crystalline structure and transforming it to an amorphous aluminosilicate phase $\left(\mathrm{Al}_{2} \mathrm{O}_{3} \cdot 2 \mathrm{SiO}_{2}\right)$ that is also called metakaolinite. This process, known as dehydroxylation [4] of kaolinite, is strongly affected by the heating parameters, such as temperature, heating rate and time, as well as from the cooling rate at ambient conditions. A quantitative criterion to evaluate the performance of calcination process is the dehydroxylation degree $\left(D_{d}\right)$ of kaolinite, according to Eq. (1) [6]:

$$
D_{d}=1-\left(m / m_{\max }\right)
$$

Where, $m$ is the residual mass loss of the sample and $m_{\max }$ is the maximum mass loss, which is equal to the L.O.I. of crude kaolin taken from chemical analysis (Table 1). Based on the results of mass loss obtained from the calcination experiments and the L.O.I. value of kaolin, the dehydroxylation degree of kaolinite calculated by Eq. (1) is shown in Fig. 1 as a function of temperature (Fig. 2a) and time (Fig. 2b).
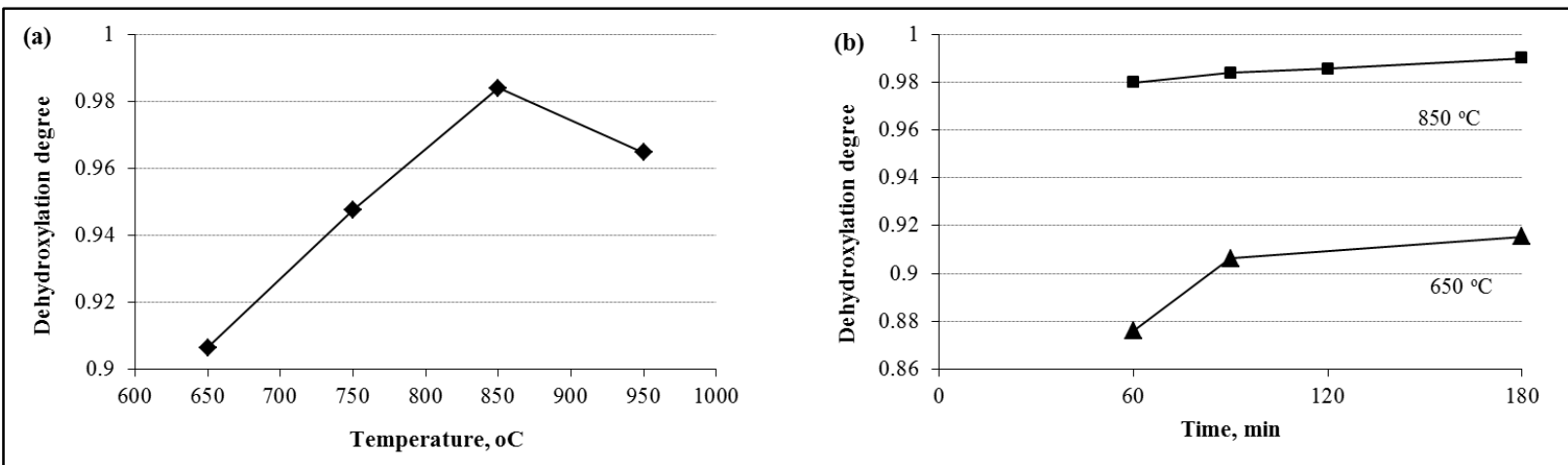

Fig. 1: Dehydroxylation degree of kaolinite after calcination (a) at different temperatures, 120 min and (b) for different times.

As can be seen in Fig. 1 (a), the highest degree of kaolinite's dehydroxylation was achieved after calcination at $850{ }^{\circ} \mathrm{C}$. At this temperature, the increase of time improved slightly the dehydroxylation degree (Fig. 2b). In particular, a dehydroxylation degree equal to 0.98 was achieved after 60 min calcination at $850{ }^{\circ} \mathrm{C}$, indicating a nearly complete transformation of kaolinite to the amorphous metakaolinite. Based on these results, calcination of kaolin for leaching experiments was decided to take place at $850{ }^{\circ} \mathrm{C}$ for $120 \mathrm{~min}$.

\subsection{Hydrometallurgical Treatment of Calcined Kaolin}

In Fig. 2, the extraction of $\mathrm{Al}$ and $\mathrm{Si}$ from the calcined kaolin is given as a function of leaching time and the acidsolution used. According to Fig. 2(a), the leaching of $\mathrm{Al}$ from the calcined kaolin with $\mathrm{HCl}, \mathrm{HNO}_{3}, \mathrm{H}_{2} \mathrm{SO}_{4}$ and $\mathrm{C}_{2} \mathrm{H}_{2} \mathrm{O}_{4}$ is a fast process and totally completed after $6 \mathrm{~h}$. After that time, the rate of $\mathrm{Al}$ extraction was kept constant with the exception of $\mathrm{HCl}$, for which a slightly negative rate was observed, indicating possible re-precipitation of $\mathrm{Al}$ extracted to insoluble phases. According to the experimental results, the highest extraction of $\mathrm{Al}$, about $86 \%$, was achieved with the $\mathrm{HNO}_{3}$ solution. The extraction of $\mathrm{Al}$ with $\mathrm{HCl}$ and $\mathrm{H}_{2} \mathrm{SO}_{4}$ reached $82 \%$ and $76 \%$, respectively, while oxalic acid achieved $79 \%$ extraction of Al. However, the $\mathrm{Al}$ extraction with mineral acid-solutions was accompanied by a high Si extraction, as seen in Fig. 2(b), which comprises an important impurity for the alumina produced. In opposite, the extraction of Si with the organic acids used was very low. Especially in the case of $\mathrm{C}_{2} \mathrm{H}_{2} \mathrm{O}_{4}$, the leaching of Si was about $4.5 \%$ after $6 \mathrm{~h}$, making oxalic acid the most promising candidate for the extraction of aluminium from kaolin.

As seen in Fig. 2(b), after the first $6 \mathrm{~h}$ of leaching, the content of $\mathrm{Si}$ in the solution decreased sharply in $\mathrm{HCl}$ and $\mathrm{H}_{2} \mathrm{SO}_{4}$ cases, while in the case of $\mathrm{C}_{2} \mathrm{H}_{2} \mathrm{O}_{4}$, it was slightly decreased. In combination with the constant rate of Al extraction observed after the first $6 \mathrm{~h}$ (Fig. 2a), the decrease of Si content enforces the assumption of Al re-precipitation in new aluminosilicate insoluble phases. 


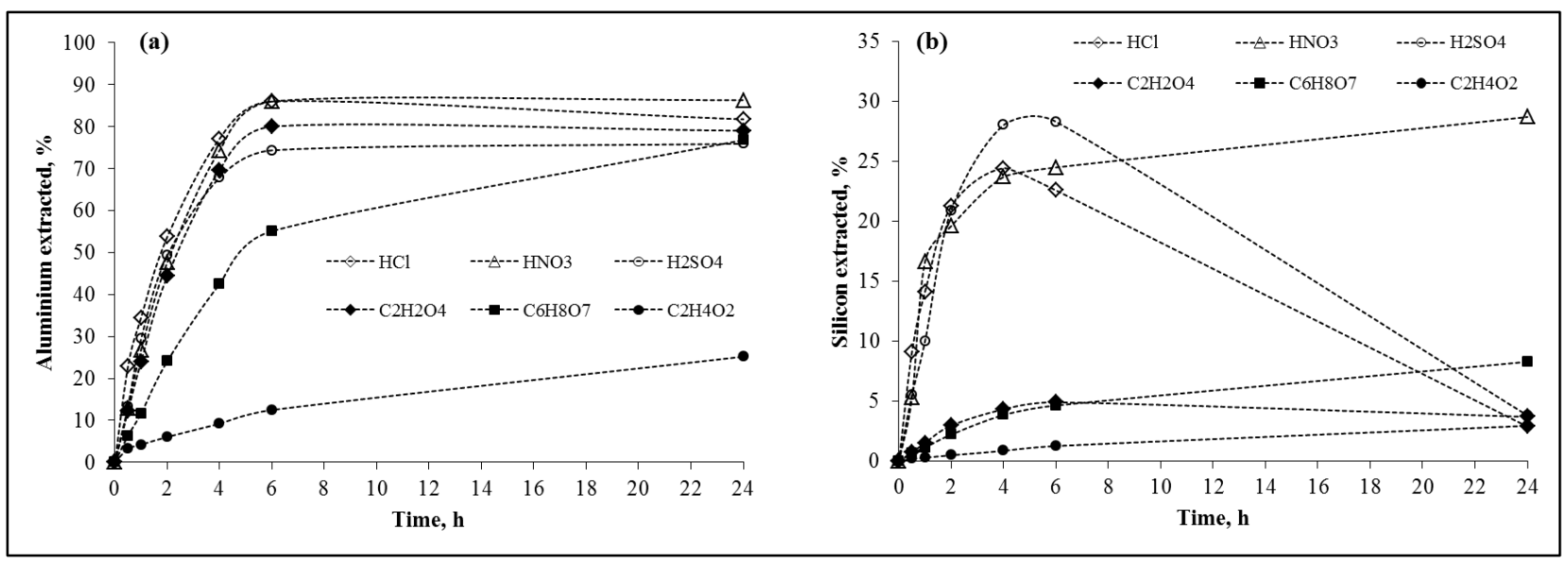

Fig. 2: Leaching of (a) aluminium and (b) silicon versus time, for the different acid-solutions used.

XRD analysis of the solids taken after acid-leaching did not revealed any mineralogical transformation or formation of new phases, comparing to the calcined kaolin. Nevertheless, according to the FTIR analysis of the same solids, new phases seems to be formed after acid-leaching, which are probably responsible for the "plateau" that presents the extraction of Al versus time in Fig. 2(a). In Fig. 3, the FTIR spectra of the solids taken after the treatment with $\mathrm{HCl}$ and $\mathrm{C} 2 \mathrm{H} 2 \mathrm{O} 4$ are given as representative and are compared with the FTIR spectrum of the calcined kaolin.

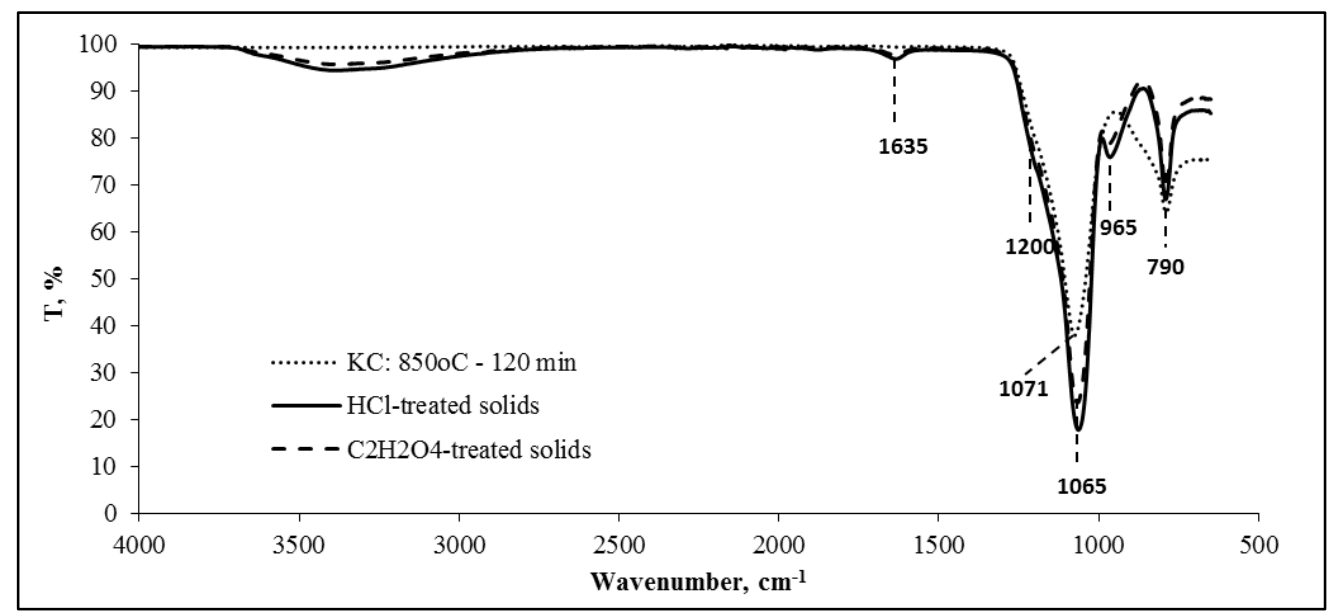

Fig. 3: FTIR spectra of the calcined kaolin and the solids after treatment with $\mathrm{HCl}$ and $\mathrm{C}_{2} \mathrm{H}_{2} \mathrm{O}_{4}$.

As shown in Fig. 3, the spectra of the solids after the treatment with $\mathrm{HCl}$ and $\mathrm{C} 2 \mathrm{H} 2 \mathrm{O} 4$ show new bands, comparing to the spectrum of the calcined kaolin. The broad band at the range $3500-3100 \mathrm{~cm}-1$ and the peak at $1635 \mathrm{~cm}-1$ are related to the physically adsorbed water and assigned as stretching and bending vibrations of $\mathrm{OH}-$, respectively. The shoulder that starts to be formed at $\sim 1200 \mathrm{~cm}-1$ is attributed to the vibration of $\mathrm{Si}-\mathrm{O}$, in addition to that at $1065 \mathrm{~cm}-1$. The new band appeared at $965 \mathrm{~cm}-1$ is attributed to the stretching vibrations of silanol groups that are formed during the acid treatment of calcined kaolin [7]. Acid leaching process leads to the reorganization of the SiO4 sheets of metakaolinite after Al3+ dissolution, giving rise to silanol and siloxane groups. The formation of these phases consumes Al, justifying the negative rate of $\mathrm{Al}$ extraction observed after the first $6 \mathrm{~h}$ of leaching with $\mathrm{HCl}$ solution, as well as to the constant $\mathrm{Al}$ extraction rate observed after the same time, in the cases of the other mineral acids used and the oxalic acid (Fig. 2a).

The results from the hydrometallurgical treatment of the calcined kaolin with the different bases solutions used are given in Fig. 4, in which the extraction of $\mathrm{Al}$ (Fig. 4a) and Si (Fig. 4b) is given as a function of time. As shown in Fig. 4(a), the ammonia solution did not achieve to extract $\mathrm{Al}$ from the calcined kaolin. $\mathrm{NaOH}$ and $\mathrm{KOH}$ solutions leached $\mathrm{Al}$ very fast and reached an optimum after the first hour. At the same time and in both cases of $\mathrm{KOH}$ and $\mathrm{NaOH}$ solutions, $\mathrm{Si}$ extraction is also high. After that time, the rate of $\mathrm{Al}$ extraction became negative (in case of $\mathrm{NaOH}$ ) or kept constant (in 
case of $\mathrm{KOH}$ ), until the end of the process, indicating $\mathrm{Al}$ re-precipitation to form insoluble phases. Si extraction presented the same trend with $\mathrm{Al}$ extraction, in both cases of the above mentioned base-solutions (Fig. 5b), supporting the formation of aluminosilicate insoluble phases.

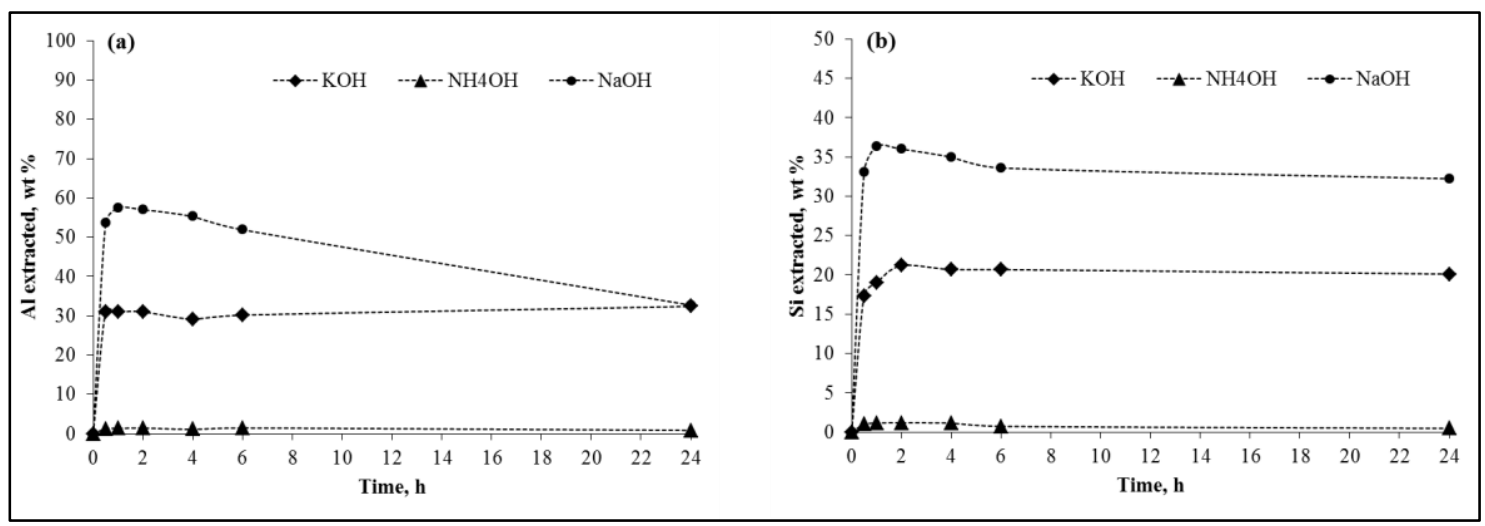

Fig. 4: Leaching of (a) aluminium and (b) silicon versus time, for the different base-solutions used.

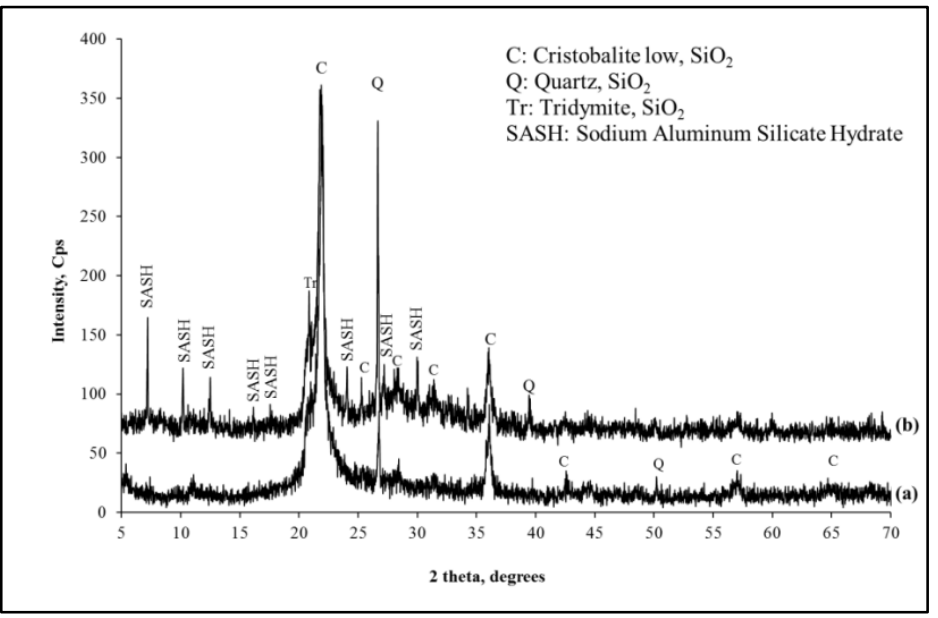

Fig. 5: XRD analysis of (a) calcined kaolin and (b) the solids after leaching with $\mathrm{NaOH}$ solution.

The formation of such phases is confirmed by the XRD analysis of the solids after leaching. As shown in Fig. 5, where the XRD spectrum of the solids treated with $\mathrm{NaOH}$ solution is compared to the XRD spectrum of the calcined kaolin, a new, quite amorphous phase consisting of $\mathrm{Na}, \mathrm{Al}$ and $\mathrm{Si}$ is formed, justifying the negative rate of $\mathrm{Al}$ extraction after the first hour of leaching process. The XRD result is in clear agreement with the FTIR results given in Fig. 6.

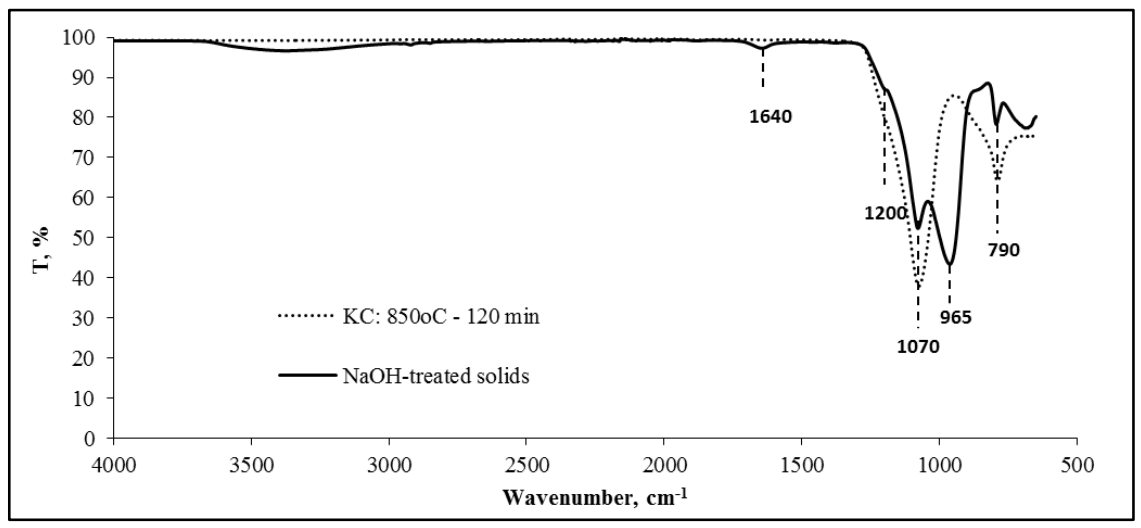

Fig. 6: FTIR spectra of the calcined kaolin and the solids after treatment with $\mathrm{NaOH}$ solution. 
As shown in Fig.6, the new peak assigned to the formation of silanol groups at $965 \mathrm{~cm}^{-1}$ became more intense, comparing to that of the acid-treated solids (Fig. 3). Combining that observation with the decreased peak at $1070 \mathrm{~cm}^{-1}$ attributed to $\mathrm{Si}-\mathrm{O}$ stretching vibration mode, it should be assumed that there are structural changes of the tetrahedral $\mathrm{Si}$ existing in the calcined kaolin, which are related with the dissolution of Si and its re-precipitation in new phases.

\section{Conclusions}

Based on the experimental results presented in this paper, the extraction of $\mathrm{Al}$ from kaolin clays by leaching is more effective with the use of acids than of bases. Among the studied acids, oxalic acid seems to be the most attractive leaching agent for the extraction of $\mathrm{Al}$ from the calcined kaolin, as it limits the simultaneous Si extraction. The optimization of the leaching process is subject of a farther investigation. Moreover, the production of high grade alumina to be used for aluminium production is necessary to be investigated, in order for the proposed hydrometallurgical process to have industrial interest.

\section{References}

[1] A. A. Al-Zahrani and M. H. Abdul-Majid, "Extraction of Alumina from Local Clays by Hydrochloric Acid Process," JKAU: Eng. Sci., vol. 20, no. 2, pp. 29-41, 2009.

[2] G.-A. Olaremu, "Sequential Leaching for the Production of Alumina from a Nigerian Clay," IJETMAS, vol. 3, no. 7, ISSN 2349-4476, 2015.

[3] A. W. Al-Ajeel and S. I. Al-Sindy, "Alumina recovery from Iraqi kaolinitic clay by hydrochloric acid route," Iraqi Bulletin of Geology and Mining, vol. 2, no. 1, pp. 67-76, 2006.

[4] M. Murat and M. Driouche, "Chemical reactivity of thermally activated clay minerals," Cem. Concr. Res., vol. 18, pp. 221-228, 1988.

[5] P. Numluk and A. Chaisena, "Acid and Ammonium Sulfate Leaching of Alumina from Lampang Clay," E-Journal of Chemistry, vol. 9, no. 3, pp. 1364-1372, 2012.

[6] H. Rahier, B. Wullaert and B. Van Mele, "Influence of the degree of dehydroxylation of kaolinite on the properties of aluminosilicate glasses," J. Therm. Anal. Calorim., vol. 62, pp. 417-427, 2000.

[7] K. Okada, A. Shimai, T. Takei, S. Hayashi, A. Yasumori and K. D. J. KacKenzie, "Preparation of microporous silica from metakaolinite by selective leaching method," Microporous and Mesoporous Materials, vol. 21, pp. 289-296, 1998. 